\title{
Evidence of in utero infection by Mycobacterium avium subsp. paratuberculosis using Multiple-Locus Variable-number tandem-repeat Analysis: first report in Argentina
}

\section{Evidência de infecção intra-uterina por Mycobacterium avium subsp. paratuberculosis usando Multiple-Locus Variable-number tandem-repeat Analysis: primeiro relato na Argentina}

\author{
Brenda Vasini Rosell ${ }^{1,2}$; Bernardo Lagleyze ${ }^{3}$; Claudia Morsella ${ }^{2}$; Laura Mendez²; Florencia Bresky ${ }^{2,4}$; \\ Andrea Gioffré ${ }^{1,5}$; Fernando Paolicchi ${ }^{2,4}$ (D) \\ ${ }^{1}$ Conselho Nacional de Pesquisa Científica e Tecnológica, Buenos Aires, Argentina \\ ${ }^{2}$ Estação Experimental Agrícola INTA, Laboratório de Bacteriologia, Balcarce, Argentina \\ ${ }^{3}$ Autônomo, Balcarce, Argentina \\ ${ }^{4}$ Universidade Nacional de Mar del Plata, Faculdade de Ciências Agrícolas, Balcarce, Argentina \\ ${ }^{5}$ Instituto de Agrobiotecnologia e Biologia Molecular, Castelar, Argentina
}

\begin{abstract}
A pregnant heifer with an advanced clinical stage of paratuberculosis was reported in a herd in Argentina. Thus, the animal was euthanized and samples of organs of the cow and its fetus was taken and cultured for bacteriology in specific medium. Tissues were analyzed by histopathology (hematoxylin-eosin and Ziehl-Neelsen staining). Histopathological analysis of the cow's samples revealed the presence of lesions consistent with paratuberculosis, and Ziehl-Neelsen staining revealed the presence of acid-fast bacilli, whereas the fetal tissues showed absence of lesions but the presence of acid-fast bacilli by Ziehl-Neelsen staining. After growing in specific medium, colonies in tissues from both cow and fetus were positive for IS900-PCR, confirming the presence of Mycobacterium avium subsp. paratuberculosis (MAP). Finally, the isolates were typed by Multiple-Locus Variable-number tandem-repeat Analysis (MLVA), which confirmed the epidemiological link between them. This study is the first in Argentina to report the detection of MAP that shares an identical MLVA type in a pregnant cow and its fetus. The results of this study are consistent with previous reports and highlight the intra-uterine transmission of MAP as an important source of infection within herds.
\end{abstract}

Keywords: Paratuberculosis. In utero infection. Molecular diagnosis. Bovine fetus.

RESUMO

Uma novilha prenha em estado clínico avançado de paratuberculose foi observada em um rebanho bovino na Argentina. O animal foi eutanasiado e foram colhidas amostras dos seus órgãos e dos órgãos feto as quais foram cultivadas para bacteriologia em meio específico. Os tecidos foram examinados por histopatologia (coloração de hematoxilina-eosina e Ziehl-Neelsen). Na histopatologia das amostras colhidas da novilha foram observadas lesões compatíveis com paratuberculose e a coloração de Ziehl-Neelsen revelou a presença de bacilos álcool-ácido resistentes, nos tecidos fetais não foram observadas lesões, porém a coloração de Ziehl-Neelsen revelou a presença de bacilos álcool-ácido resistentes. Após o crescimento em meio específico, as colônias foram positivas para o teste IS900-PCR nos tecidos de ambos, vaca e feto, confirmando a presença de Mycobacterium avium subsp. paratuberculosis. Por fim, os isolados foram tipados por Multiple-Locus Variable-number tandem-repeat Analysis, confirmando a relação epidemiológica entre eles. Este estudo relata a primeira detecção de Mycobacterium avium subsp. paratuberculosis na Argentina em que houve o compartilhamento de um tipo idêntico de MLVA em uma vaca prenhe e no seu feto. Os resultados deste estudo são consistentes com relatos anteriores e destacam a transmissão intra-uterina de Mycobacterium avium subsp. paratuberculosis como importante fonte de infecção nos rebanhos de bovinos.

Palavras-chave: Paratuberculose. Infecção uterina. Diagnóstico molecular. Feto bovino. 
Correspondence to:

Fernando Paolicchi

Estação Experimental Agrícola INTA, Laboratório de

Bacteriologia

Ruta 226, km 73,5, CP 7620

Balcarce, Buenos Aires, Argentina

e-mail: paolicchi.fernando@inta.gob.ar

Received: September 01, 2019

Approved: January 15, 2020

How to cite: Vasini Rosell B, Lagleyze B, Morsella C, Mendez L, Bresky F, Gioffré A, Paolicchi F. Evidence of in utero infection by Mycobacterium avium subsp. paratuberculosis using Multiple-Locus Variable-number tandem-repeat Analysis: first report in Argentina. Braz J Vet Res Anim Sci. 2020;57(1):e161653. https://doi.org/10.11606/issn.1678-4456.bjvras.2020.161653

Johne's disease or bovine paratuberculosis (PTBC) is an enteric disease caused by the intracellular bacterium Mycobacterium avium subsp. paratuberculosis (MAP) (Salem et al., 2013). In Argentina, with one of the largest herds worldwide (Espeschit et al., 2017), Johne's disease represents a main problem of great importance. Furthermore, there is no control program to reduce the impacts of the disease (Whittington et al., 2019). Although there is no current data of the economic loses that this disease cause in the country, an estimated loss of 28 million dollars for beef and dairy cattle, was reported in the Salado basin, placed in Buenos Aires province, a region with high prevalence of PTBC (Traversa et al., 2005).

The main difficulty in controlling PTBC disease is its long incubation time followed by an intermittent shedding of the bacterium to the environment (Espejo et al., 2012; Koets et al., 2015). The most common mode of transmission is the postnatal fecal-oral transmission (Soto et al., 2002) because calves are especially susceptible in the first months of life until the first year (Sweeney, 2011). Nevertheless, other modes of transmission, including in utero infection, were earlier identified (Sweeney, 1996). The first report dates from 1929 in Germany, when acid-alcohol-resistant forms were described in the blood, liver, and other fetal tissues from an unborn fetus that belonged to a cow clinically affected with PTBC (Alexejeff-Goloff, 1929). Since then, several studies have confirmed that calves born to MAP-seropositive cows are 6.6 times more likely to be seropositive than calves born to MAP-seronegative cows (Aly \& Thurmond, 2005). A previous meta-analysis study estimated that $9 \%$ of fetuses born to subclinically infected dams and $39 \%$ of clinically affected dams are in utero infected with MAP, thus representing a major risk factor to the maintenance of the infection within herds (Whittington \& Windsor, 2009).

In order to confirm in utero infection, molecular analysis seems to be the most suitable method, as it provides consistent information about the infectious strain. Despite the fact that whole genome sequencing provides an extreme discrimination between strains, its cost prevents routine use in developing countries. Multiple-Locus Variable-number tandem-repeat Analysis (MLVA) (Thibault et al., 2007) is one of the most used method worldwide for MAP genotyping (Fawzy et al., 2016), due to its relative simplicity, low economic cost and the possibility to compare results with other studies by using the online database (MAC-INMV-SSR Database, 2019).

Thus, the aim of this work was to confirm a case of in utero infection of PTBC by tissue and fecal culture and subsequent molecular subtyping to characterize all the MAP isolates.

A herd of Aberdeen Angus beef cattle located in Buenos Aires province, Argentina, with a high prevalence of PTBC in heifers and cows, was tested by ELISA and fecal culture. From 2001 to 2012, PPA-ELISA testing was performed as screening to establish the measures to reduce the impact of the disease in the herd. During that period of monitoring and control, the seroprevalence was reduced from $7.17 \%$ to $1.02 \%$. However, due to different reasons, the owner decided to interrupt the monitoring program and, two years later, new clinical cases were reported in the herd. A pregnant heifer (6-8 months of pregnancy) with an advanced clinical stage of the disease with progressive weight loss, submandibular edema, diarrhea and pronounced physical weakness was selected from this herd to be studied. The poor prognosis suggested the euthanasia of the animal, which was performed in accordance with the recommendations of the National Council of Animal Experimentation Control. The animal was identified as \#907-K32.

Serum and fecal samples were obtained before euthanasia to perform an in house indirect ELISA (iELISA) (Paolicchi et al., 2003) and bacteriological analysis, respectively.

According to the iELISA based on the PPA antigen (Allied Monitor, France), the serum samples were classified as seronegative when the absorbance index $(\mathrm{AI}) \leq 1.5$, seropositive for $\mathrm{AI} \geq 2.1$ or not-conclusive for AI between 1.6 and 2.0.

At necropsy, sterile samples of ileocecal valve, mesenteric lymph nodes and large intestine were taken for bacterial isolation in Herrold's egg yolk medium supplemented with mycobatin J (HEYM) (Paolicchi et al., 2003) and further IS900-PCR. A tissue section was fixed in 10\% buffered formalin for histopathological analysis. The uterus was sent to 
the laboratory to perform pathological studies and the fetus was taken aseptically under biosecurity conditions. Tissue samples from intestine, mesenteric lymph node, liver, kidney and lung, and body fluids were taken for bacterial isolation and histopathological analysis using hematoxylin-eosin stain (HE) combined with Ziehl-Neelsen stain (ZN) to detect acid fast bacilli. The gestational age of the fetus was estimated ( 6 months). The fetus was identified as \#907-K37.

After approximately 90 days of culture, a loopful was taken and genomic DNA was obtained using spin columns (Qiagen DNeasy ${ }^{\circledR}$ Blood \& Tissue kit, Germany) and then were tested by IS900-PCR (Collins et al., 1993). The products were resolved by electrophoresis in $1 \%$ agarose gel. The isolates were typed by Multiple-Locus Variable-number tandem-repeat Analysis (MLVA). For this purpose, eight different MIRU-VNTR markers were typed as described by Thibault et al. (2007) and designated VNTR292, MIRUX3, VNTR25, VNTR47, VNTR3, VNTR7, VNTR10 and VNTR32. The primers and PCR conditions were as suggested by Thibault et al. (2007) with minor modifications: the annealing temperature for locus 47 was decreased in $1{ }^{\circ} \mathrm{C}$ during the first 10 cycles from $69^{\circ} \mathrm{C}$ to $59{ }^{\circ} \mathrm{C}$ and then set at $64^{\circ} \mathrm{C}$ for 35 cycles, whereas the annealing temperature for locus 292 was decreased in $2{ }^{\circ} \mathrm{C}$ and set at $56^{\circ} \mathrm{C}$.

The PCR products were resolved by 3.5\% agarose gel electrophoresis and the product size was estimated using a 100-bp DNA marker (INBIO Highway, Argentina) and a 50-bp DNA marker (Promega, USA) depending on the size of the expected product. In order to determine the numerical profile of each strain, we used the INRA-Nouzilly MIRU-VNTR (INMV) database from the National Institute of Agronomic Research (INRA), France. DNA from the reference strain MAP ATCC 19698 (INMV 2) and DNA from the local strain 01/861-F64 (INMV 1) were included as controls.
The macroscopic observation of organs from the cow showed granulomatous enteritis and enlarged edematous lymph nodes. Thickening of the small intestine wall, inflammation of the lymphatic vessels and a typical brain aspect were also observed, confirming the pathognomonic lesions of the disease. The histological study confirmed granulomatous lymphadenitis and granulomatous diffuse enteritis with presence of giant cells, lymphocyte cells and mononuclear inflammatory infiltrate (Figure 1). Finally, this was confirmed by the isolation of MAP in culture from these tissues and feces after 90 days of culture. Tissue samples from the fetus were also positive. The iELISA result was not conclusive (AI: 1.9).

Regarding the fetus, although tissues showed absence of macroscopic lesions, the presence of acid fast bacilli was later revealed in the intestine and mesenteric lymph nodes by positive Ziehl-Neelsen staining of tissue samples. Lymph nodes cultures were also positive after 90 days of growth.

IS900-PCR confirmed the isolates from both cow and fetus as MAP. Further molecular analysis involving the MLVA typing method confirmed that both isolates shared the same pattern, called INMV 1 (Figure 2). This pattern appears to be the most frequent in Argentina according to some authors (Gioffré et al., 2015; Imperiale et al., 2017) and our own research over 90 MAP isolates (data not published).

In recent years, $\mathrm{PTBC}$ has generated great interest because of its increasing worldwide prevalence, especially among dairy cattle which is the most affected, leading to severe economic losses and even health concerns for the rural workers since MAP has been associated to Crohn's disease in humans (García \& Shalloo, 2015; McNees et al., 2015). The gold standard technique to diagnose PTBC is the culture of the bacterium in specific media, usually from a sample of feces. However, at early stages of the disease, this may be unreliable. The detection of MAP in feces, milk or tissues to detect and

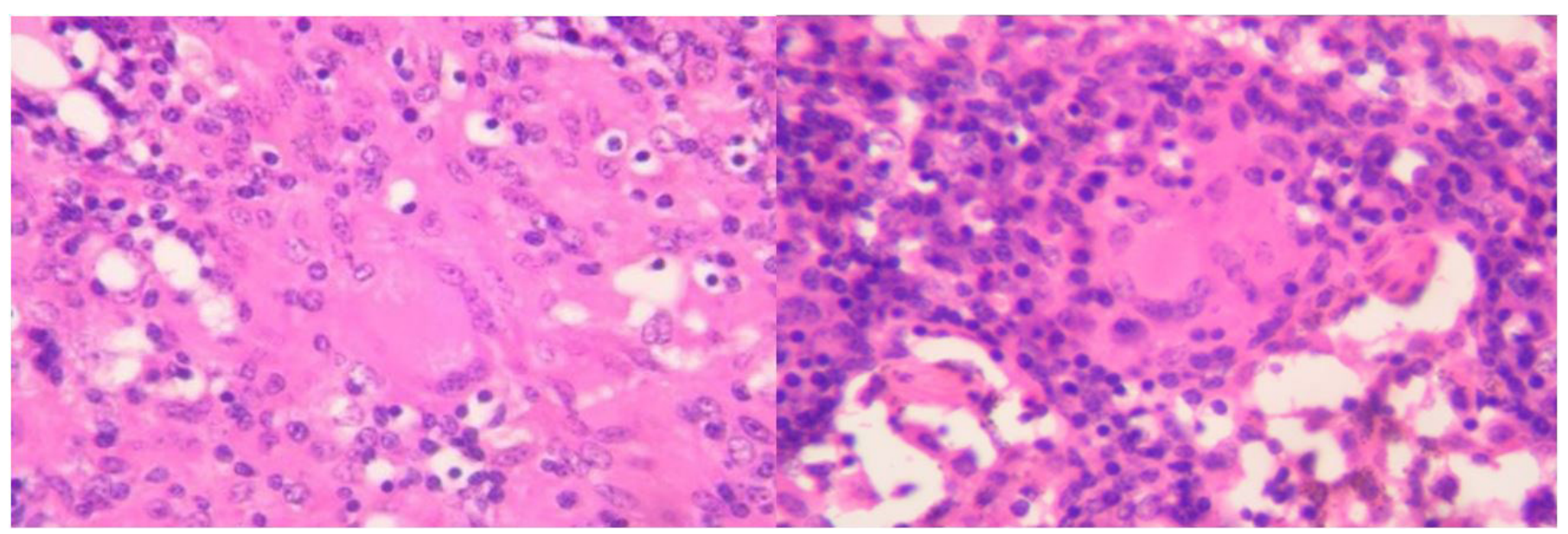

Figure 1 - Histopathological findings in cow \#907-K32. Diffuse granulomatous enteritis with the presence of giant cells, lymphocyte cells and mononuclear inflammatory infiltrate. H/E, 100X. 

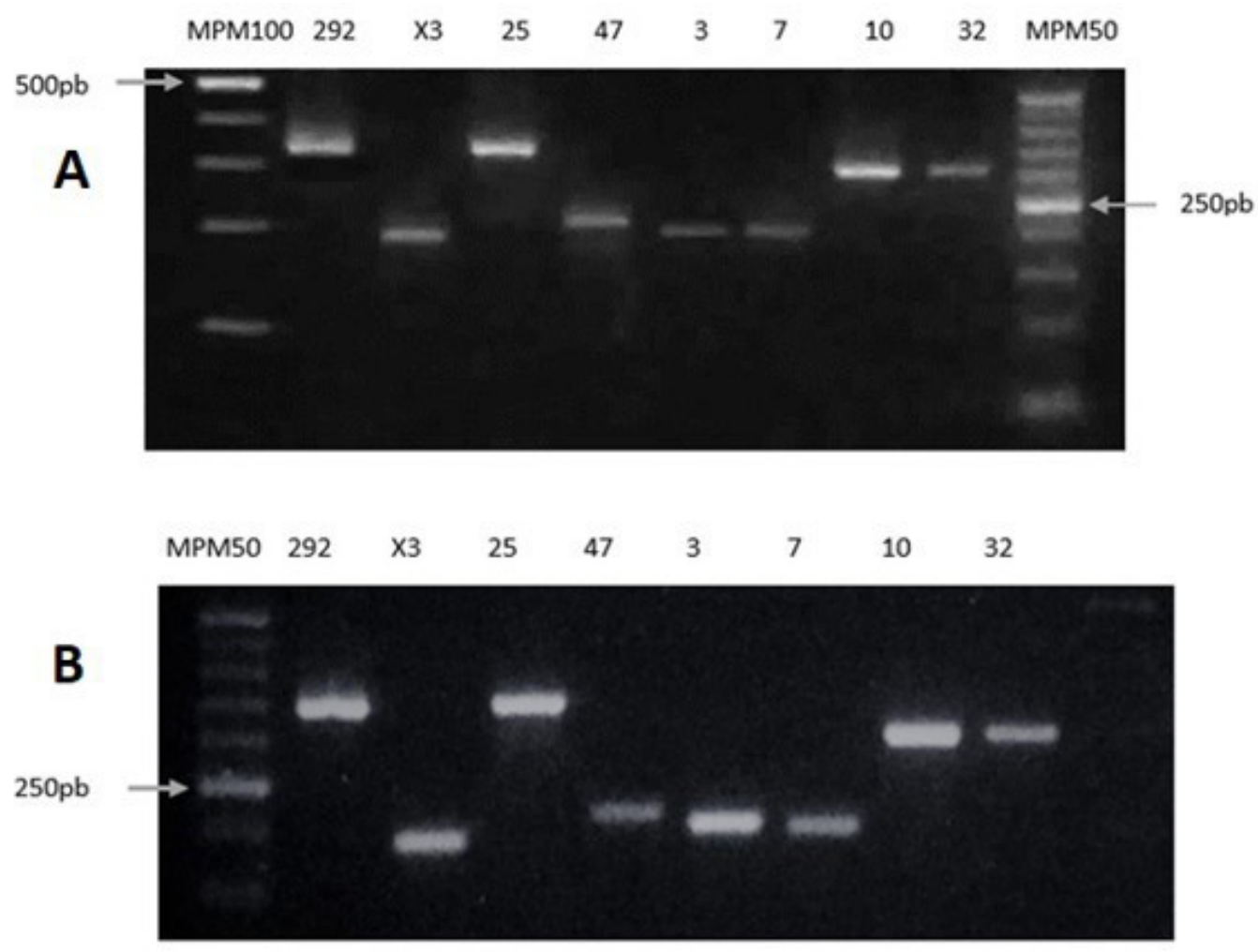

Figure $2-3.5 \%$ agarose gel corresponding to MAP strains to the cow (A) and the fetus studied (B).

remove infected animals has an economic impact on the dairy industry and could have great impact on food safety.

The genus Mycobacterium develops complex mechanisms of interaction with the host and generally has more than one mechanism of transmission among animals (Manning, 2001). While the fecal-oral path is the most common and accepted mechanism of transmission, other pathways such as in utero infection may be a limiting factor to eradicate. Infected newborns are not easily diagnosed and, as a consequence, are not eliminated in time (Whittington \& Windsor, 2009).

Several studies have demonstrated that between $20 \%$ and $40 \%$ of fetal infection occurs in fetuses born to mothers clinically affected with PTBC (Belo-Reis et al., 2016; Sweeney et al., 1992). Seitz et al. (1989) reported that 26.4\% of newborn calves from PTCB-positive pregnant cows have a risk of fetal infection. The detection of MAP DNA by PCR in fetal fluids and various fetal tissues supports the concept of Johne's disease as a disseminated infectious disease (Buergelt \& Williams, 2003). and should draw attention to avenues of transmission other than the traditional fecal-oral pathway. However, according to the same study and in agreement with our results, the fetal histological lesions seems to be non-specific.

The fetal abomasum content is a common sample to take at necropsy to test for several pathogens. Nevertheless, in the present study, the clinical sample that allowed us to detect the presence of MAP in the fetus was the fetal mesenteric lymph node and intestine, which is in accordance with the tropism of the bacterium in the adult host.

Our findings represent the first description of in utero infection of PTBC in Argentina, confirmed by the isolation of the same strain of MAP by application of MLVA. This study also represents a relevant episode that highlights the importance of a correct diagnosis and the subsequent elimination of positive cows from the herd, avoiding the permanence of carrier animals that may transmit the disease to other animals and to their offspring. This study also proves the importance of molecular-based identification and typing of MAP to confirm PTBC diagnosis and the genomic relation between two or more isolates, which represents an important tool in epidemiological studies.

\section{Conflict of Interest}

The authors state that they have no conflicts of interest to declare.

\section{Ethics Statement}

The ethics and animal welfare statutes were fulfilled.

\section{Acknowledgements}

None. 


\section{References}

Alexejeff-Goloff NA. Zur frage der pathogenese und bazillenausscheidung bei Rinderparatuberkulose. Zeitschr Infekt Haus. 1929;36:313-7.

Aly SS, Thurmond MC. Evaluation of Mycobacterium avium subsp. paratuberculosis infection of dairy cows attributable to infection status of the dam. J Am Vet Med Assoc. 2005;227(3):450-4. http://dx.doi.org/10.2460/ javma.2005.227.450. PMid:16121613.

Belo-Reis AS, Salvarani FM, Brito MF, Fonseca AA, Silva NS, Silveira JAS, Barbosa JD. Intrauterine Infection by Mycobacterium avium subsp. paratuberculosis in buffalo (Bubalus bubalis). J Vet Sci Med Diagn. 2016;5(1):2-6.

Buergelt C, Williams E. In utero infection of pregnant cattle by Mycobacterium avium subsp. paratuberculosis detected by nested polymerase chain reaction. Int J Appl Res Vet Med. 2003;1:279-84.

Collins DM, Stephens DM, De Lisle GW. Comparison of polymerase chain reaction tests and faecal culture for detecting Mycobacterium paratuberculosis in bovine faeces. Vet Microbiol. 1993;36(3-4):289-99. http://dx.doi. org/10.1016/0378-1135(93)90095-O. PMid:7794290.

Espejo LA, Godden S, Hartmann WL, Wells SJ. Reduction in incidence of Johne's disease associated with implementation of a disease control program in Minnesota demonstration herds. J Dairy Sci. 2012;95(7):4141-52. http://dx.doi. org/10.3168/jds.2011-4550. PMid:22720971.

Espeschit IF, Schwarz DGG, Faria ACS, Souza MCC, Paolicchi FA, Juste RA, Carvalho IA, Moreira MAS. Paratuberculosis in Latin America: a systematic review. Trop Anim Health Prod. 2017;49(8):1557-76. http://dx.doi.org/10.1007/ s11250-017-1385-6. PMid:28884331.

Fawzy A, Zschöck M, Ewers C, Eisenberg T. New polymorphisms within the variable number tandem repeat (VNTR) 7 locus of Mycobacterium avium subsp. paratuberculosis. Mol Cell Probes. 2016;30(3):132-7. http://dx.doi.org/10.1016/j. mcp.2016.02.002. PMid:26872530.

Garcia AB, Shalloo L. Invited review: the economic impact and control of paratuberculosis in cattle. J Dairy Sci. 2015;98(8):5019-39. http://dx.doi.org/10.3168/jds.20149241. PMid:26074241.
Gioffré A, Correa Muñoz M, Alvarado Pinedo MF, Vaca R, Morsella C, Fiorentino MA, Paolicchi F, Ruybal P, Zumárraga M, Travería GE, Romano MI. Molecular typing of Argentinian Mycobacterium avium subsp. paratuberculosis isolates by multiple-locus variable number-tandem repeat analysis. Braz J Microbiol. 2015;46(2):557-64. http://dx.doi. org/10.1590/S1517-838246220140283. PMid:26273274.

Imperiale BR, Moyano RD, Di Giulio AB, Romero MA, Alvarado Pinedo MF, Santangelo MP, Traveria GE, Morcillo NS, Romano MI. Genetic diversity of Mycobacterium avium complex strains isolated in Argentina by MIRU-VNTR. Epidemiol Infect. 2017;145(7):1382-91. http://dx.doi. org/10.1017/S0950268817000139. PMid:28166858.

Koets AP, Eda S, Sreevatsan S. The within host dynamics of Mycobacterium avium ssp. paratuberculosis infection in cattle: where time and place matter. Vet Res. 2015;46(1):61. http:// dx.doi.org/10.1186/s13567-015-0185-0. PMid:26092382.

MAC-INMV-SSR Database [Internet]. 2019 [cited 2019 Sept 1]. Available from: http://mac-inmv.tours.inra.fr/

Manning EJB. Mycobacterium avium subsp. paratuberculosis: a review of current knowledge. JZoo Wildl Med. 2001;32(3):293304. http://dx.doi.org/10.1638/1042-7260(2001)032[0293:MA SPAR]2.0.CO;2. PMid:12785677.

McNees AL, Markesich D, Zayyani NR, Graham DY. Mycobacterium paratuberculosis as a cause of Crohn's disease. Expert Rev Gastroenterol Hepatol. 2015;9(12):152334. http://dx.doi.org/10.1586/17474124.2015.1093931. PMid:26474349.

Paolicchi FA, Zumarraga MJ, Gioffre A, Zamorano P, Morsella C, Verna A, Cataldi A, Alito A, Romano M. Application of different methods for the diagnosis of paratuberculosis in a dairy cattle herd in Argentina. J Vet Med. 2003;50(1):206. http://dx.doi.org/10.1046/j.1439-0450.2003.00606.x. PMid:12710496.

Salem M, Heydel C, El-Sayed A, Ahmed SA, Zschöck M, Baljer G. Mycobacterium avium subsp paratuberculosis an insidious problem for the ruminant industry. Trop Anim Health Prod. 2013;45(2):351-66. http://dx.doi.org/10.1007/ s11250-012-0274-2. PMid:23054804.

Seitz SE, Heider LE, Heuston WD, Bech-Nielsen S, Rings DM, Spangler L. Bovine fetal infection with Mycobacterium 
paratuberculosis. J Am Vet Med Assoc. 1989;194(10):14236. PMid:2722634.

Soto JP, Kruze J, Leiva S. Comparison of three different methods for the diagnosis of bovine-Paratuberculosis in infected dairy herds. Med Vet. 2002;34(2):265-73.

Sweeney RW. Transmission of paratuberculosis. Vet Clin North Am Food Anim Pract. 1996;12(2):305-12. http:// dx.doi.org/10.1016/S0749-0720(15)30408-4. PMid:8828107.

Sweeney RW. Pathogenesis of paratuberculosis. Vet Clin North Am Food Anim Pract. 2011;27(3):537-46, v. http:// dx.doi.org/10.1016/j.cvfa.2011.07.001. PMid:22023832.

Sweeney RW, Whitlock RH, Rosenberger AE. Mycobacterium paratuberculosis isolated from fetuses of infected cows not manifesting signs of the disease. Am J Vet Res. 1992;53(4):47780. PMid:1586015.

Thibault VC, Grayon M, Boschiroli ML, Hubbans C, Overduin P, Stevenson K, Gutierrez MC, Supply P, Biet F. New variable-number tandem-repeat markers for typing Mycobacterium avium subsp. paratuberculosis and M. avium strains: comparison with IS900 and IS1245 restriction fragment length polymorphism typing. J Clin Microbiol. 2007;45(8):2404-10. http://dx.doi.org/10.1128/JCM.0047607. PMid:17537942.

Traversa MJ, Alcobedo J, Schettino DM, Sanz HE, Rodriguez EM, Olmos MR, Jorge MC. Pérdidas económicas de un rodeo con paratuberculosis en el oeste de la provincia de Buenos Aires, Argentina. Rev Argent Prod Anim. 2005;25(1):336-7.

Whittington R, Donat K, Weber D, Kelton S, Nielsen S, Eisenberg N, Arrigoni R. Control of paratuberculosis: who, why and how: a review of 48 countries. BMC Vet Res. 2019;15(198).

Whittington RJ, Windsor PA. In utero infection of cattle with Mycobacterium avium subsp. paratuberculosis: a critical review and meta-analysis. Vet J. 2009;179(1):60-9. http:// dx.doi.org/10.1016/j.tvjl.2007.08.023. PMid:17928247.

Financial Support: This work was funded by the project PNSA INTA I-103, 2019 of the National Institute of Agricultural Technology (INTA - Argentina). 